\title{
EXAMINING THE EFFECTS OF ARTIFICIAL CRANIAL MODIFICATION ON CRANIOFACIAL METRICS
}

\author{
EXAMINANDO LOS EFECTOS DE LA MODIFICACIÓN ARTIFICIAL \\ CRANEAL EN MÉTRICA CRANEOFACIALES
}

\author{
Christine E. Boston ${ }^{1, *}$, Drew Smith ${ }^{2,3}$, Carlos Ubeda ${ }^{4}$, Mayorie Chandia ${ }^{4}$, \\ and Mariel Gonzale ${ }^{4}$
}

\begin{abstract}
Studies focusing on biological differences among groups have been a widespread area of anthropological research for decades. One of the most common means of assessing biological differences is through comparing craniofacial metrics. Craniofacial growth is under genetic control but strongly influenced by environmental factors, including artificial cranial modification (ACM). Some scholars believe ACM affects craniofacial metrics, but other scholars disagree. This study seeks to remedy this debate. A total of 218 adult crania (101 unmodified, 117 modified) from coastal and inland sites of three northern Chilean valleys were surveyed and examined for craniofacial metric changes through the use of modern orthodontic cephalometric analyses. Unmodified crania were statistically tested with the hierarchical linear analysis test to determine if there were any differences based on site, region (coast vs. inland), period, or sex within the unmodified sample, followed by a comparison of these data to modified cranial data. Statistical tests, specifically the ANOVA test, of the data determined that ACM affected some but not all craniofacial measurements utilized in this study. This conclusion, coupled with the varying conclusions of similar previously conducted studies, suggests that scholars must be cautious in employing modified crania and craniofacial metrics in any study of biological affinities.
\end{abstract}

Key words: Artificial cranial modification, craniofacial metrics, cephalometry, bioarqueología, Andes.

Los estudios centrados en las diferencias biológicas existentes entre distintos grupos se han constituido, por varias décadas, en una amplia área de estudio en el campo de la investigación antropológica. Una de las formas más comunes de evaluar estas diferencias biológicas es mediante la comparación de las medidas craneofaciales. El crecimiento craneofacial es controlado genéticamente, pero está fuertemente influenciado por factores ambientales, incluyendo la modificación artificial del cráneo (ACM). Algunos investigadores piensan que la ACM afecta las medidas craneofaciales, mientras otros no están de acuerdo, afirmando que no existe efecto. Este estudio tiene como objetivo aportar a este debate. Un total de 218 cráneos de adultos (101 sin modificar, 117 modificados), provenientes de sitios costeros e interiores de tres valles del norte de Chile fueron estudiados y examinados en búsqueda de cambios en las medidas craneofaciales, mediante uso de análisis de ortodoncia cefalométrica moderna. Los cráneos no modificados fueron primero analizados estadísticamente con la prueba del análisis lineal jerárquico para determinar si había diferencias basadas en el lugar o región de origen (costa vs interior), período, o sexo, posteriormente se realizó una comparación de estos datos con los datos recogidos de los cráneos modificados. Las pruebas estadísticas, específicamente la prueba de ANOVA, determinaron que ACM afectó algunas, pero no todas las mediciones craneofaciales utilizadas en este estudio. Esta conclusión, junto con diferentes conclusiones de estudios similares realizados anteriormente, sugiere que los investigadores deben tener cuidado en el empleo de cráneos modificados y medidas craneofaciales en cualquier estudio sobre las diferencias biológicas entre grupos.

Palabras claves: modificación artificial del cráneo, medidas craneofaciales, cefalometría, bioarqueología, Andes.

\footnotetext{
1 Department of Anthropology, University of Western Ontario, London, ON N6A 3K7.

2 School of Medicine and Dentistry, University of Western Ontario, London, ON N6A 3K7.

3 Smith Orthodontics, 602 Oxford Street E., London, ON N5Y 3J1. drdrew@ smithorthodontics.ca

4 Departamento de Tecnología Médica, Universidad de Tarapacá, Arica, Chile.

* Corresponding Author: 1620 Kings Row, Reno, NV 89503, T: (217) 556-8117. cboston@ tmcc.edu
} 
The most common means of determining biological affinities among groups has been the use of specific cranial features, including epigenetic traits and craniofacial metrics (cf. Guillén 1992; Hrdlička 1939; Morton 1839; Oetteking 1930). The skull is made up of several regions (Bishara 2001), and its growth is believed to be interrelated among various hard and soft tissues. The complex relationships of craniofacial growth are summarized in the Functional Matrix Hypothesis (Moss 1960, 1962, 1969), which maintains skeletal tissue growth responds to corresponding soft tissues as related to the form and function of each matrix. While the greater part of cranial growth completes during late childhood, growth of the facial tissues is mostly completed during adolescence, although these facial tissues will continue to change throughout an individual's life (Enlow and Hans 2008). Craniofacial growth is believed to be primarily under genetic control, but several studies demonstrate that environmental factors can delay or accelerate craniofacial growth (Behrents 1985; Brace and Hunt 1990; Corruccini 1974; Enlow and Hans 2008; Mackey 1977; Moyers and Enlow 1988; Ranly 1988). The role these environmental changes play in craniofacial growth patterns is particularly important as it is well documented that growth disruptions or changes in the cranial vault and cranial base will directly affect craniofacial measurements (Enlow and Hans 2008).

Craniofacial metrics are widely used in physical anthropological studies concerning biological affinities. The use of craniofacial metrics to determine biological affinities works on the premise that individuals of similar biological origin or affinity will share common craniofacial morphology and therefore measurements, while those of different origin or affinity will demonstrate statistically significant differences in craniofacial morphology in comparison to other groups (Howells 1973, 1989, 1995; Morton 1839). Studies of the environmental factors affecting craniofacial metrics are widespread, with scholars identifying environmental factors such as health, nutrition, geography, climate, biocultural modifications, among others affecting growth (e.g. Buretic-Tomljanovic et al. 2007; Corruccini 1974; Droessler 1981; Mackey 1977; Smith et al. 2007; Spradley 2006). One biocultural modification believed to affect cranial growth is artificial cranial modification.

Artificial cranial modification (ACM) is the manipulation of the cranial vault through the use of externally applied forces in order to change the natural form of the skull (Anton and Weinstein 1999; Gerszten 1993; Perez 2007). Two primary types have been identified: intentional and unintentional modification. Intentional modification is the purposeful act of modifying the cranium, whereas unintentional modification is the accidental reshaping of the skull or changes due to genetics, health, hormones, nutrition, accidents, or sleeping posture (Dingwall 1931; Flowers 1881; Gerszten 1993; Rogers 1975). ACM was practiced by many groups of varying social complexity (Dingwall 1931), as well as among groups on each habitable continent, although the distribution of this practice varied geographically (Dingwall 1931). ACM began shortly after birth, when the skull was most plastic and malleable (Dingwall 1931). The cranium was wrapped, bound, and/or affixed to the preferred deformation device, including but not limited to stones, boards, leaves, reeds, textiles, caps, ropes, and cradles (Dingwall 1931; de Landa 1975 [15241579]; Morton 1839; Weiss 1961). ACM devices were subsequently removed at variable times, all dependent on cultural preferences. The total time frame ranged from one year to five years (Dingwall 1931; Morton 1839; Torquemada 1995; Weiss 1961), comprising the early growth and development stages of craniofacial growth.

There exists a widespread debate concerning how ACM affects the craniofacial skeleton and hence craniofacial metrics. Despite a great deal of study, no clear consensus has been reached. Some scholars affirm that facial measurements are affected, regardless of modification styles and populations surveyed (Anton 1989; Bjork and Bjork 1964; Brown 1981; Cheverud et al. 1992; Cheverud and Midkiff, 1992; Cybulski 1975; Frieß and Baylac 2003; Kohn et al. 1993; Manriquez et al. 2006; Oetteking 1930; Pomeroy et al. 2010; Rhode and Arriaza 2006), and some believe no changes occur (Blackwood and Danby 1955; Ross and Ubelaker 2009; Rothhammer et al. 1982; Verano 1987). The breadth of study on this topic emphasizes that scholars have not reached a unanimous decision regarding the full effects of ACM on facial metrics. These results are problematic as scholars continue to disagree on which measurements are affected, even when similar modification styles or populations are studied.

The unknown effects of ACM are particularly problematic given the popularity of craniofacial 
measurements in biological distance studies. The effects of ACM on craniofacial metrics may be clarified through the utilization of an established approach not readily employed: orthodontic cephalometry. This method was utilized to determine if, and to what extent, ACM affected craniofacial measurements in this sample, and how these effects relate to biological distance analyses.

\section{Materials and Methods}

Materials for the craniofacial measurement analyses were derived from ancient northern Chilean populations of the Azapa, Camarones, and Lluta valleys that spanned a several millennia from the Archaic to Late periods (Table 1). These individuals are currently housed at the Museo Arqueológico Universidad de Tarapacá, San Miguel de Azapa (MASMA) in Arica, Chile. A total of 218 adults (101 unmodified crania, 117 modified crania) were used for the study due to the requirement of the mandible for the cephalometric analyses despite the availability of more crania in the museum collections (Table 2). Both modified and unmodified crania were surveyed.

These samples included individuals from both coastal and inland sites from the Archaic to Late periods as identified by MASMA collection records.
These groups practiced their own unique cultures with coastal groups specializing in marine exploitation and inland groups specializing in agricultural practices. Several scholars believe that several periods, from the Formative to the Late periods, were characterized by highland migration into the region (Berenguer and Dauelsberg 1989; Goldstein 2005; Moraga et al. 2005; Muñoz 1987; Piazza 1981; Rivera 1977; Rivera 2008; Rothhammer et al. 2002; Santoro 1980a, 1980b, 1980c; Santoro 1981; Santoro and Ulloa 1985; Varela and Cocilovo 2002), and that coastal and inland groups represented isolated ethnic groups that remained in contact for trade purposes but possibly did not intermarry (Cassman 1997; Cassman 2000; Focacci 1974; Focacci 1993; Focacci and Chacón 1989; Muñoz 1981; Muñoz 1989; Rivera 2008; Santoro 1980a, 1980b, 1980c).

An inventory and data collection, including sexing and aging, was completed for all individuals. Only the cranium of each individual was examined due to the nature of the collections available at the time of data collection. Sex determinations were based on cranial morphology methods (Acsadi and Nemeskeri 1970). Age-at-death determinations were based on dental eruption of the third molar, indicating adult age status (Ubelaker 1999). In adults, suture closure methods were deemed inaccurate for these individuals since modification can affect the

Table 1. Sample Composition.

Composición de la muestra.

\begin{tabular}{|c|c|c|c|c|c|c|c|c|c|}
\hline Period & Dates & $\begin{array}{c}\text { Coastal } \\
\text { Sites }\end{array}$ & $\begin{array}{l}\text { Sample } \\
\text { Size }\end{array}$ & Males & Females & $\begin{array}{c}\text { Inland } \\
\text { Sites }\end{array}$ & $\begin{array}{c}\text { Sample } \\
\text { Size }\end{array}$ & Males & Females \\
\hline \multirow[t]{2}{*}{ Late Period } & \multirow[t]{2}{*}{ AD 1476-1532 } & Camarones 8 & 8 & 3 & 5 & Azapa 8 & 17 & 8 & 9 \\
\hline & & Camarones 9 & 8 & 2 & 6 & Lluta 54 & 5 & 4 & 1 \\
\hline \multirow{6}{*}{$\begin{array}{l}\text { Regional } \\
\text { Development } \\
\text { Period }\end{array}$} & \multirow[t]{6}{*}{ AD 1100-1476 } & \multirow[t]{6}{*}{ None } & \multirow[t]{6}{*}{0} & \multirow[t]{6}{*}{0} & \multirow[t]{6}{*}{0} & Azapa 6 & 17 & 6 & 11 \\
\hline & & & & & & Azapa 11 & 1 & 1 & 0 \\
\hline & & & & & & Azapa 71 & 36 & 15 & 21 \\
\hline & & & & & & Azapa 76 & 3 & 2 & 1 \\
\hline & & & & & & Azapa 140 & 49 & 18 & 31 \\
\hline & & & & & & Azapa 141 & 8 & 5 & 3 \\
\hline Middle Horizon & AD 500-1100 & None & 0 & 0 & 0 & None & 0 & 0 & 0 \\
\hline \multirow[t]{2}{*}{ Formative Period } & \multirow[t]{2}{*}{1500 BC-AD 500} & \multirow[t]{2}{*}{ Playa Miller 7} & \multirow[t]{2}{*}{14} & \multirow[t]{2}{*}{9} & \multirow[t]{2}{*}{5} & Azapa 70 & 10 & 3 & 7 \\
\hline & & & & & & Azapa 75 & 14 & 8 & 6 \\
\hline \multirow[t]{4}{*}{ Archaic Period } & \multirow[t]{3}{*}{$4000-1500 \mathrm{BC}$} & Morro 1 & 13 & 7 & 6 & None & 0 & 0 & 0 \\
\hline & & Morro 1-6 & 11 & 8 & 3 & & & & \\
\hline & & Quiani 7 & 4 & 4 & 0 & & & & \\
\hline & Total & & 58 & 33 & 25 & Total & 160 & 70 & 90 \\
\hline
\end{tabular}


Table 2. Cranial form by site composition.

Formas craneanas por sitio.

\begin{tabular}{lcccc}
\hline Site & $\begin{array}{c}\text { Number of } \\
\text { Unmodified } \\
\text { Crania }\end{array}$ & $\begin{array}{c}\text { Number of } \\
\text { Annularly } \\
\text { Modified Crania }\end{array}$ & $\begin{array}{c}\text { Number of } \\
\text { Fronto-Occipitally } \\
\text { Modified Crania }\end{array}$ & Total \\
\hline Azapa 6 & 7 & 2 & 8 & 17 \\
Azapa 8 & 7 & 9 & 1 & 17 \\
Azapa 11 & 0 & 0 & 1 & 1 \\
Azapa 70 & 6 & 3 & 1 & 36 \\
Azapa 71 & 15 & 6 & 8 & 14 \\
Azapa 75 & 1 & 5 & 0 & 3 \\
Azapa 76 & 2 & 1 & 16 & 49 \\
Azapa 140 & 24 & 9 & 5 & 8 \\
Azapa 141 & 3 & 0 & 0 & 8 \\
Camarones 8 & 6 & 1 & 0 & 5 \\
Camarones 9 & 8 & 0 & 1 & 13 \\
Lluta 54 & 4 & 1 & 1 & 11 \\
Morro 1 & 7 & 5 & 2 & 14 \\
Morro 1-6 & 5 & 5 & 3 & 4 \\
Playa Miller 7 & 6 & 6 & 63 & 218 \\
Quiani 7 & 0 & 1 & & 8 \\
\hline Total & 101 & 54 & & 5 \\
\hline
\end{tabular}

timing of their closures (O'Brien and Sensor 2008). Additional means of determining age among adults (e.g. dental wear patterns) could not be completed due to the scarcity of materials available (e.g. broken or missing teeth).

Cranial modifications were scored based on the typology created by Hrdlička (1912). This typology was chosen as it was derived from Andean populations and was deemed the most appropriate typology to utilize for this sample as it did not overly divide the sample, thereby weakening the statistical analyses by creating small sample sizes. This typology identifies two modification styles: annular and fronto-occipital. Annular modification, which is also sometimes referred to as circumferential modification, is a conical variation of the cranial form with reshaping occurring among several bones, including the frontal, temporal, inferior portions of the parietals, and occipital bones, and is believed to be caused by the application of wrapped materials (Hrdlička 1912). Fronto-occipital modification is characterized by the flattening of both the frontal and occipital bones and is believed to be caused by the application of flat materials (Hrdlička 1912). Both styles were practiced with great frequency among Andean groups (Blom 2005; Dingwall 1931; Hrdlička 1912; Morton 1839; Torres-Rouff 2002; Torres-Rouff 2009). Crania were identified as unmodified if no evidence of purposeful modification was present. Crania with evidence of accidental or slight modification were excluded from the study.

Each skull was X-rayed in order to facilitate further analyses related to the craniofacial metric changes related to ACM through cephalometric analyses. X-rays were taken on Kodak T-Mat G/ RA Diagnostic Film with a Shimadzu EZY-RAD VA-125P-CH X-ray machine. X-rays were taken by the author with assistance from Dr. Carlos Ubeda, Mayorie Chandia, and Mariel Gonzalez at MASMA, and Chandia and González completed film development also at MASMA. X-rays were taken at five feet from the midsagital plane of each skull as recommended in standard cephalometric analyses in order to avoid distortion in the image from X-raying (Miyashita 1996). If any distortions in images did occur it is believed that they were consistent among all the individuals as all were $\mathrm{x}$-rayed in the same manner. Analyses of the X-rays were completed by the authors at a private orthodontic facility in London, Ontario.

Cephalometry, or measurements of the living head, is a technique developed by anthropologists and refined by Holly Broadbent to quantify shape and sizes of skulls (Broadbent 1931). These analyses involve the identification of hard and soft tissue facial landmarks and taking specific measurements 
to trace the growth and development of faces in order to track growth patterns (Miyashita 1996). They have been widely used in the field of modern orthodontics for several decades and have also been utilized in the fields of pedodontics, oral surgery, plastic surgery, prosthodontics, and general dentistry (Miyashita 1996). Cephalometric protocols have been refined and are widely used for the purpose of correcting growth maladies related to the face.

Cephalometric analyses were conducted using the Kodak Orthotrac software (Kodak Orthotrac Practice Management Software Installation Guide 2009). This program employs scans of X-rays to map internal and external facial landmarks, located by the user, and takes various measurements based on the type of analysis utilized. A new analysis routine was created by Kodak Orthotrac utilizing a suite of measurements and angles chosen by the authors. These measurements were chosen based on expected changes induced within the cranial base and face or solely the face in order to test the hypothesis ACM changed the facial convexity, height, and location of the mandible (Riolo et al. 1974). These measurements were also chosen as they did not utilize soft tissue landmarks, which are commonplace in many establish cephalometric protocols. Furthermore, established cephalometric protocols (e.g. Ricketts, Jarabak, or Downs analyses) were rendered inappropriate to use for this type of sample as there were very few purely hard tissue measurements as these protocols were established for practice with living patients and utilize primarily soft and hard tissue measurements, meaning the useable data with these protocols were significantly reduced.

It is expected, based on normal facial growth directions, that ACM would interrupt or halt normal growth by creating an increase in facial convexity and facial heights by interfering with the growth of the spheno-occipital synchondrosis in the forward and downward directional growth pattern (following Cohen 2006; Enlow and Hans 2008; Moyers and Enlow 1988; Proffett 2007). It is easiest to increase facial measurements with modification as demonstrated in modern orthodontic practice (Smith personal communication 2012), and therefore it is expected that all surveyed facial measurements would demonstrate an increase in size among modified as compared to unmodified individuals. This strategy of focusing on facial convexity, height, and mandibular location was considered optimal for this study given the methods used in analyses. This strategy, however, is by no means the only one utilized as various facial measurements and orientations (e.g. facial breadth, frontal plane, etc.) have been studied in many of the previous studies focusing on facial metric changes as related to artificial cranial modification styles.

The measurements chosen and expected outcomes are outlined in Table 3. The requested measurements were input into the new analysis (Figure 1). Only individuals with mandibles available can be surveyed in cephalometric analyses as it was determined in a pilot study that this method could not be effectively exploited without the mandible present (Boston et al. 2008). Mandibles were placed so that maxillary and mandibular dentitions were in occlusion. This method is not ideal as actual mandibular position is dependent on soft tissues, but the consistency in mandible placement among modified and unmodified individuals is not believed to have greatly affected the results of this study.

The cephalometric data for annularly and fronto-occipitally modified individuals were separately compared to the unmodified individuals. The measurements of the unmodified sample were ultimately grouped together as there was a lack of statistically significant differences by site, region (coast vs. inland), period, or sex when the data were tested with the hierarchical linear analysis statistical test. This pooling of the data allowed for an increase in the sample size and power of the statistical tests used in this study, as well. An average non-modified value for each measurement was determined after completion of the above statistical analyses, and these average values were used as the "standard" unmodified cephalometric values for comparison between the modified and unmodified individuals (Table 4). The standard values were input into the new cephalometric analysis by Kodak to create a new analytical routine specified for the project. Modified individuals were then traced and compared to the measurements of the new analysis. Upon completion of all tracings, the measurements (as determined by the established Orthotrac software) were compared with the ANOVA test to determine if similar differences existed for each measurement among annular and fronto-occipital modification styles and unmodified crania.

As the purpose of this study was to determine if ACM affects facial measurements and the extent of any changes that may exist, the following null 
Table 3. Facial Measurements Used in Cephalometric Analyses (after Riolo et al. 1974).

Medidas faciales utilizadas en los análisis cefalométricos (por Riolo et al. 1974).

\begin{tabular}{lccc}
\hline Measurement & Points & Type of Measurement & Expected Change \\
\hline Sella-Nasion-A-point & A-N-S & Angular & Increase \\
Sella-Nasion-Frankfort Plane & N-S/Or-Po & Angular & Increase \\
Sella-Nasion-Palatal Plate & N-S/ANS-PNS & Angular & Increase \\
Sella-Nasion-Gnathion & N-S/PTM-SE & Angular & Increase \\
Sella-Nasion-Basion & N-S-Ba & Angular & Increase \\
Condylar Plane/Sella-Gnathion & Or-Co/GN-S & Angular & Increase \\
Nasion-Pogonion/Mandibular Plane & Go-Me/N-Pg & Angular & Increase \\
Anterior Nasal Spine-Nasion & ANS-N & Linear & Increase \\
Sella-Nasion & S-N & Linear & Increase \\
Basion-Nasion & Ba-N & Linear & Increase \\
Menton-Nasion & Me-N & Linear & Increase \\
\hline
\end{tabular}

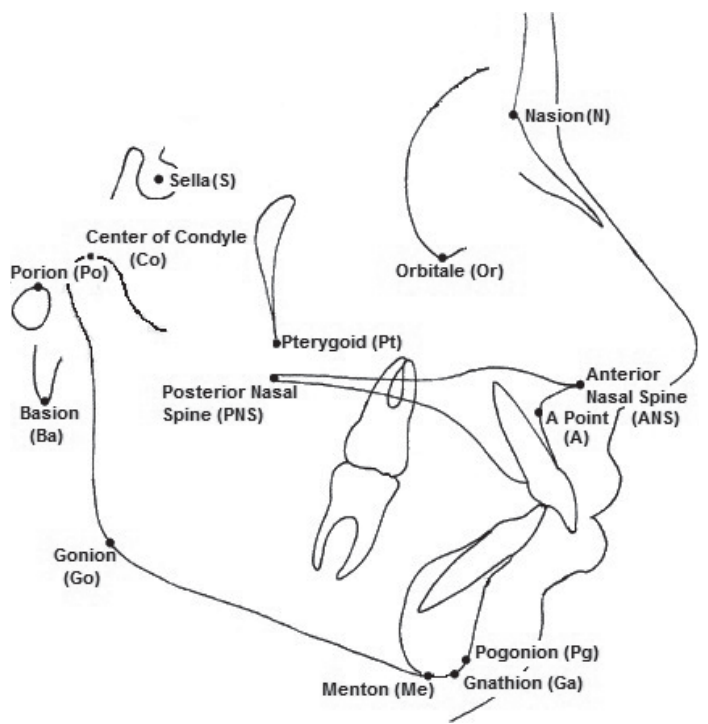

Figure 1. New cephalometric analysis (after Kodak Orthotrac). Nuevo análisis cefalométrico (después de Kodak Orthotrac).

hypothesis was tested: ACM had no effect on facial growth and therefore craniofacial metrics. This hypothesis would be rejected if cephalometric measurement differences are demonstrated between modified and unmodified individuals, which would mean that craniofacial metrics may not be used to discern biological differences among groups for modified individuals. If, however, this hypothesis was not rejected, modified and unmodified crania may be used in biological affinity studies utilizing craniofacial metric analyses.

\section{Results}

The analysis compared the craniofacial measurements attained from each of the modification
Table 4. Comparison of the Hrdlička modification styles and unmodified cranial cephalometric measurements (ANOVA). Comparación de los estilos de modificación de Hrdlička y sin modificación para cefalométricas craneal (ANOVA).

\begin{tabular}{lcc}
\hline Cephalometric Measurements & $\begin{array}{c}\text { ANOVA } \\
\text { P-Value }\end{array}$ & $\begin{array}{c}\text { Degrees } \\
\text { of } \\
\text { Freedom }\end{array}$ \\
\hline Sella-Nasion-A-point (A) & $.032^{*}$ & 217 \\
Sella-Nasion-Frankfort Plane (A) & .199 & 217 \\
Sella-Nasion-Palatal Plate (A) & .389 & 217 \\
Sella-Nasion-Gnathion (A) & .717 & 217 \\
Sella-Nasion-Basion (A) & $.015^{*}$ & 217 \\
Condylar Plane/Sella-Gnathion (A) & .630 & 217 \\
Nasion-Pogonion/Mandibular Plane (A) & $.016^{*}$ & 217 \\
Anterior Nasal Spine-Nasion (L) & .167 & 217 \\
Sella-Nasion (L) & .140 & 217 \\
Basion-Nasion (L) & .103 & 217 \\
Menton-Nasion (L) & .334 & 217 \\
\hline
\end{tabular}

*Statistically Significant $(\mathrm{P}=0.05)$.

styles identified in the Hrdlička typology to unmodified individuals using the ANOVA test. The results demonstrated three measurements with statistically significant differences among the two modification styles and unmodified crania (Table 4). These measurements included the Sella-NasionA-point, an angular measurement that measures the convexity of the face in relation to the location of the maxilla, Sella-Nasion-Basion, an angular measurement that examines the general convexity of the face, and Nasion-Pogonion/Mandibular Plane, which measures the medio-vertical angle based on the anterior portion of the face. Overall, there was no difference in the Sella-Nasion-A-point measurement between annularly modified and unmodified 
individuals, but fronto-occipitally modified individuals demonstrated a slight but significant increase for this measurement. Annularly modified individuals demonstrated a slight but significant decrease while fronto-occipitally modified individuals demonstrated a slight but significant increase in the Sella-Nasion-Basion measurement when compared to unmodified individuals. Individuals with annular or fronto-occipital modification demonstrated statistically significant increased measurements in the Nasion-Pogonion/Mandibular Plane measurement as compared to unmodified individuals (Table 5).

These results demonstrate that ACM does affect specific facial measurements. They do not, however, completely agree with the expectations. It was expected that both modification styles would increase the effected measurements, which occurred with the Nasion-Pogonion/Mandibular Plane measurement. Fronto-occipital modification caused an increase in the Sella-Nasion-A-point and Sella-Nasion-Basion measurements. Annular modification demonstrated a decrease in the Sella-Nasion-Basion measurement but no difference in the Sella-Nasion-A-point measurement. The differences in the results between the two ACM styles are not unexpected and most likely due to the pressures associated with the ACM devices to form radically different modification styles. The increase in the measurements among the fronto-occipital modification style could be due to the pressures on the occipital, which would have pushed the sphenoid (sella) up, causing the face (nasion) to compensate accordingly when the facial growth occurred during adolescence. The pressures on the frontal and occipital bones associated with annular modification could have caused a decrease in measurements if the device lay low on the forehead, closer to the nose (nasion), causing the face to compensate accordingly.

\section{Discussion and Conclusion}

These results demonstrate that ACM does affect some facial measurements but not all, which is an incomplete rejection of the null hypothesis. This result is in agreement with previous analyses that also noted some facial change occurred in ACM crania (e.g. Anton 1989; Bjork and Bjork 1964; Brown 1981; Cheverud et al. 1992; Cybulski 1975; Frieb and Baylac 2003; Kohn et al. 1993; Manríquez et al. 2006; Oetteking 1930; Pomeroy et al. 2010; Rhode and Arriaza 2006) but particularly with Anton (1989), Brown (1981), Cheverud et al. (1992), Cybulski (1975), Oetteking (1930), and Rhode and Arriaza (2006), that latter of which utilized some of the same northern Chilean populations in their study, who noted similar facial measurement changes found in this study, in the modified crania they surveyed.

Table 5. Means and standard deviations of the Hrdlička typology and unmodified cranial cephalometric measurements (rounded to nearest $100^{\text {th }}$ ).

Promedios y desviaciones estándar de las Tipologías Hrdlička y de las Mediciones Craneales Cefalométricas sin modificar (redondeadas a la centésima más cercana).

\begin{tabular}{|c|c|c|c|c|c|c|}
\hline \multirow[t]{2}{*}{ Measurements } & \multicolumn{2}{|c|}{$\begin{array}{l}\text { Unmodified Crania } \\
\qquad(\mathrm{N}=101)\end{array}$} & \multicolumn{2}{|c|}{$\begin{array}{l}\text { Annularly Modified Crania } \\
\qquad(\mathrm{N}=54)\end{array}$} & \multicolumn{2}{|c|}{$\begin{array}{l}\text { Fronto-Occipitally } \\
\text { Modified Crania } \\
\qquad(\mathrm{N}=66)\end{array}$} \\
\hline & Mean & $\begin{array}{c}\text { Standard } \\
\text { Deviation }\end{array}$ & Mean & $\begin{array}{l}\text { Standard } \\
\text { Deviation }\end{array}$ & Mean & $\begin{array}{l}\text { Standard } \\
\text { Deviation }\end{array}$ \\
\hline Sella-Nasion-A-point & 85.75 & 4.95 & 85.57 & 4.45 & 87.54 & 4.74 \\
\hline Sella-Nasion-Frankfort Plane & 4.76 & 3.62 & 6.04 & 4.09 & 5.65 & 3.78 \\
\hline Sella-Nasion-Palatal Plate & 6.88 & 3.54 & 7.56 & 3.45 & 6.90 & 3.40 \\
\hline Sella-Nasion-Gnathion & 70.52 & 4.73 & 70.95 & 5.0635 & 69.54 & 4.70 \\
\hline Sella-Nasion-Basion & 18.89 & 2.92 & 17.79 & 2.6596 & 19.26 & 2.62 \\
\hline Condylar Plane/Sella-Gnathion & 67.45 & 4.77 & 68.15 & 4.8875 & 68.03 & 4.95 \\
\hline Nasion-Pogonion/Mandibular Plane & 60.58 & 4.70 & 61.88 & 4.6525 & 62.88 & 5.82 \\
\hline Anterior Nasal Spine-Nasion & 52.22 & 3.52 & 52.60 & 3.2040 & 53.30 & 3.93 \\
\hline Sella-Nasion & 65.56 & 4.85 & 66.18 & 4.8405 & 64.52 & 4.04 \\
\hline Basion-Nasion & 104.68 & 7.18 & 107.57 & 8.1573 & 105.61 & 8.54 \\
\hline Menton-Nasion & 123.85 & 8.90 & 124.72 & 8.2664 & 123.41 & 8.64 \\
\hline
\end{tabular}


The expectation that ACM would affect facial convexity and vertical height, however, was not met, as the cephalometric analyses demonstrated that overall there were not enough facial measurement and angular changes produced that would have greatly affected either convexity or height, which is in line with similar conclusions derived from previous studies on Chilean populations (Rothhammer et al. 1982). The cephalometric measurements did demonstrate some slight and statistically significant changes in height and convexity, evidenced by the three (out of 11) measurements that were affected. As the remaining measurements were not affected, however, the few facial metric changes induced by ACM were not great enough to completely change the whole of the face. These results, however, are limited in scope as the focus of the analyses utilized herein was on facial convexity, height, and mandibular location. Other studies on additional facial measurements and orientations of the face (e.g. facial breadth, frontal plane, etc.) have yielded variable results, further demonstrating the need to further study facial metrics in relation to ACM.

There was an expectation for a greater number of changes to be present in modified individuals, and the reasons for the lack of changes may be related to the genetic nature of craniofacial growth or growth relapse. As described by Moss (1960, 1962, 1969), craniofacial growth is hypothesized to be managed by both soft and osseous tissue growth, and both genetic and environmental factors control overall growth. It may be that while ACM is an environmental (e.g. biocultural modification) factor that can redirect growth, this redirection may be strongest in areas of device placement and only indirectly affect the peripheral areas (e.g. cranial base and face). The timing at which ACM devices were removed (perhaps as late as the fifth year of life) may be too early to induce permanent changes in the peripheral area of the face, particularly since the face undergoes rapid growth during puberty (approximately seven or more years later). This lag between the removal of the ACM devices and rapid facial growth may be enough time for the remaining areas of the skull, particularly the cranial base that dictates location of many facial features, to relapse (change and be redirected) to their intended, unmodified locations (Cheverud and Midkiff 1992; Thilander 2012). This is a reality that practicing orthodontics must consider when diagnosing and treating patients as the timing of the treatment greatly affects what types of changes as well as their permanency that can be made. In modern orthodontic practice, most treatment is completed during late childhood/early adolescence as this is considered the prime time to enact permanent and effective craniofacial changes (Thilander 2012), which is not in line with the timeline for when ACM devices were utilized to change the natural form of the crania in these samples. It may be that if permanent facial changes related to ACM were caused that it was due to longer device placement or direct placement on the facial bones being affected.

In addition, other factors, such as population differences between inland and coastal groups, age-at-death, sex, may be affecting these results, but due to the nature of the sample, these factors could not be fully explored as postcranial remains were unavailable. As well, it is unclear the full effects of ACM on cranial epigenetic traits (Dorsey 1897; El Najjar and Dawson 1977; Gerszten 1993; Gottlieb 1978; Guillén 1992; O’Loughlin 2004; Ossenberg 1970; van Arsdale and Clark 2010; White 1996), rendering applicable analyses utilizing these traits difficult if not unworkable. There is an on-going debate in regards to the genetic variation that may be present in these populations. There is definitive evidence of contact between highland Andean and coastal groups, but scholars have debated the existence of gene flow from highland Andean migrants into the region (Berenguer and Dauelsberg 1989; Goldstein 2005; Moraga et al. 2005; Muñoz 1987; Piazza 1981; Rivera 1977, 2008; Rothhammer et al. 2002; Santoro 1980a, 1980b, 1980c, 1981; Santoro and Ulloa 1985; Varela and Cocilovo 2002). This potential gene flow may also be a factor that affects the craniofacial growth processes in addition to changes induced by ACM. Further study into these matters is necessary to further test the primary hypothesis of this study.

There do remain alterations to the face, and these alterations are statistically significant and warrant further review in relation to their effect on biological affinity studies on northern Chilean groups. The results of this study confirm that some craniofacial measurements among northern Chilean populations are affected and therefore cannot be used within the context of biological affinity studies. These results demonstrate that ACM does affect the facial bones, albeit in variable and in this case minimal ways. Scholars should take care in using facial metrics in 
biological affinity studies that include individuals demonstrating ACM.

In conclusion, the purpose of this study was to determine the effects of ACM on facial measurements in order to determine if and how ACM may affect biological affinity studies. The results of this analysis demonstrate that some facial measurements can and will be affected by ACM and therefore scholars should carefully scrutinize the facial measurements chosen before completing analyses using these traits. Given the variability in results among previous studies, the conservative conclusion of this study is that the specific results are only applicable to the populations and samples utilized within this analysis, but the variability in the literature on this topic should be used a cautionary tale to scholars to carefully scrutinize their methods and results to ensure maximum accuracy.
Acknowledgements: This work was supported by the Ontario Graduate Scholarship, University of Western Ontario Thesis Research Award, and GTA Union Scholarships. The authors would like to extend thanks for Dr. Bernardo Arriaza, Dr. Marietta Ortega, Vivien Standen, Octavio LagosFlores, and Natalia Escobar for their assistance in accessing collections and working in Chile. Thanks must also be extended to Dr. Andrew Nelson, Dr. Christine White, Dr. Jean-Francois Millaire, Dr. Alexis Dolphin, Dr. Jerome Cybulski, Dr. Richard Sutter, Dr. Sonia Guillén, and Christine Nelson for assistance in the completion of this work. As well, thank you to all the scholars, particularly the anonymous peer reviewers and editors of Chungara, who provided feedback on this work. Everyone's comments were very helpful and enhanced this work accordingly.

\section{References Cited}

Acsadi, G., and J. Nemeskeri 1970. History of Human Life span and Mortality. Akademiai Kiado, Budapest.

Anton, S.C. 1989. Intentional cranial vault deformation and induced changes of the cranial base and face. American Journal of Physical Anthropology 79:253-267.

Anton, S.C., and K.J. Weinstein 1999. Artificial cranial deformation and fossil Australians revisited. Journal of Human Evolution 36:195-209.

Behrents, R.G. 1985. Growth in the Aging Craniofacial Skeleton, Monograph 17, Craniofacial Growth Series. University of Michigan, Ann Arbor.

Berenguer, J., and P. Dauelsberg 1989. El norte grande en la órbita de Tiwanaku. In Culturas de Chile Prehistoria: Desde sus Origenes hasta los Albores de la Conquista, edited by J. Hidalgo, V. Schiappacasse, H. Niemeyer, C. Aldunate, and I. Solimano. Ed. Andrés Bello, pp. 129-180. Editorial Andrés Bello, Santiago.

Bishara, S.E. 2001. Textbook of Orthodontics. W.B. Saunders Company, Philadelphia.

Bjork, A., and L. Bjork 1964. Artificial deformation and craniofacial asymmetry in ancient Peruvians. Journal of Dental Research 43:353-362.

Blackwood, B. and P.M. Danby 1955. A study of artificial cranial deformation in New Britain. Journal of the Royal Anthropological Institute 85:173-191.

Blom, D.E. 2005. A bioarchaeological approach to the Tiwanaku group dynamics. In Us and Them: Archaeology and Ethnicity in the Andes, edited by R. Reycraft, pp. 153-182. University of California Press, Los Angeles.

Boston, C.E., L.E. Short, A.J. Nelson, and G. Conlogue 2008. Changes in the growth and development of the face as related to artificial cranial modification: A cephalometric analysis.
Poster Presentation at the Canadian Association of Physical Anthropology Annual Meeting, Hamilton, ON.

Brace, C.L., and K.D. Hunt 1990. A non-racial craniofacial perspective on human variation: A(ustralian) to Z(uni). American Journal of Physical Anthropology 83:341-460.

Broadbent, B.H. 1931. A New X-Ray Technique and Its Application to Orthodontia. Angle Orthodontics 1:45-66.

Brown, P. 1981. Artificial cranial deformation: a component in the variation in Pleistocene Australian Aboriginal crania. Archaeology in Oceania 16:156-167.

Buretic-Tomljanovic, A., J. Giacometti, S. Ostojic, and M. Kapovic 2007. Sex-specific differences of craniofacial traits in Croatia: the impact of environment in a small geographic area. Annals of Human Biology 34:296-314.

Cassman, V. 1997. A Reconsideration of Prehistoric Ethnicity and Status in Northern Chile: The Textile Evidence. Doctoral Dissertation, Department of Anthropology, Arizona State University, Tempe.

Cassman, V. 2000. Prehistoric ethnicity and status based on textile evidence from Arica, Chile. Chungara Revista de Antropología Chilena 32:253-257.

Cheverud, J.M., L.A.P. Kohn, L.W. Konigsberg, and S.R. Leigh 1992. Effects of fronto-occipital artificial cranial vault modification on the cranial base and face. American Journal of Physical Anthropology 88:323-345.

Cheverud, J.M., and J.E. Midkiff 1992. Effects of fronto-occipital cranial reshaping on mandibular form. American Journal of Physical Anthropology 87:167-171.

Cocilovo, J.A., H.H. Varela, and G.O. O'Brien 2010. Effects of artificial deformation on cranial morphogenesis in the south central Andes. International Journal of Osteoarchaeology 21:300-312. 
Cohen, M.M. 2006. Perspectives on the Face. Oxford University Press, Oxford.

Corruccini, R.S. 1974. An examination of the meaning of cranial discrete traits for human skeletal biological studies. American Journal of Physical Anthropology 40:425-446.

Cybulski, J.S. 1975. Skeletal Variability in British Columbia Coastal Populations: A Descriptive and Comparative Assessment of Cranial Morphology. National Museum of Canada, National Museum of Man, Mercury Series, Archaeological Survey Canada.

Dingwall, E.J. 1931. Artificial Cranial Deformation: A Contribution to the Study of Ethnic Mutilation. John Bale and Sons and Danielsson, Ltd., London.

Dorsey, G.A. 1897. Wormian bones in artificially deformed Kwakiutl Crania. American Antiquity 10:169-173.

Droessler, J. 1981. Craniometry and Biological Distance: Biocultural Continuity and Change at the Late-WoodlandMississippian Interface. Center for American Archaeology, Evanston.

El-Najjar, M.Y. and G.L. Dawson 1977. The effect of artificial cranial deformation on the incidence of Wormian bones in the lambdoidal suture. American Journal of Physical Anthropology 46:155-160.

Enlow, D.H., and M.G. Hans. 2008. Essentials of Facial Growth, $2^{\text {nd }}$ Edition. Needham Press, Inc., Ann Arbor.

Flowers, W.H. 1881. Fashion in deformity. Nature 24:480.

Frieb, M. and M. Baylac 2003. Exploring artificial cranial deformation using elliptic fourier analysis of procrustes aligned outlines. American Journal of Physical Anthropology 122:11-22.

Focacci, G. 1974. Excavaciones en Playa Miller 7. Chungara 3:23-74.

Focacci, G. 1993. Excavaciones arqueológicas en el cementerio Az-6 valle de Azapa. Chungara 24/25:69-124.

Focacci, G. and S. Chacón 1989. Excavaciones arqueológicas en los Faldeos del Morro de Arica sitios Morro 1/6 y 2/2. Chungara 22:15-62.

Gerszten, P.C. 1993. An investigation into the practice of cranial deformation among the pre-Colombian peoples of northern Chile. International Journal of Osteoarchaeology 3:87-98.

Goldstein, P. 2005. Andean Diaspora: The Tiwanaku Colonies and the Origins of South American Empire. University of Florida Press, Gainesville.

Gottleib, K. 1978. Artificial cranial deformation and the increased complexity of the lambdoid suture. American Journal of Physical Anthropology 48:213-214.

Guillén, S.E. 1992. The Chinchorro Culture: Mummies and Crania in the Reconstruction of Preceramic Coastal Adaptation. Doctoral Dissertation, Department of Anthropology, University of Michigan, Ann Arbor.

Howells, W.W. 1973. Cranial variation in man: a study by multivariate analysis of patterns of differences among recent human populations. Papers of the Peabody Museum of Archeology and Ethnology 67. Peabody Museum, Cambridge.

Howells, W.W. 1989. Skull shapes and the map: craniometric analyses in the dispersion of modern Homo. Papers of the
Peabody Museum of Archaeology and Ethnology 79. Peabody Museum, Cambridge.

Howells, W.W. 1995. Who's who in skulls: ethnic identification of crania from measurements. Papers of the Peabody Museum of Archaeology and Ethnology 82:108. Peabody Museum, Cambridge.

Hrdlička, A. 1912. Artificial deformations of the human skull with special reference to America. Actas del XVII Congreso Internacional de Americanistas, pp. 147-149, Buenos Aires.

Hrdlička, A. 1939. Practical Anthropometry. Wistar Institute of Anatomy and Biology, Philadelphia.

Kodak Orthotrac Practice Management Software Installation Guide 2009. CS OrthoTrac Practice Management Software.

Kohn, L.A.P., S.R. Leigh, S.C. Jacobs, and J.M. Cheverud 1993. Effects of annular cranial vault modification on the cranial base and face. American Journal of Physical Anthropology 90:147-168.

Mackey, J. 1977. A multivariate, osteological approach to Towa culture history. American Journal of Physical Anthropology 46:477-482.

Manríquez, G., F.E. Gonzalez-Berg, J.C. Salinas, and O. Espoueys 2006. Intentional cranial deformation in archaeological populations of Arica (Chile): preliminary geometric morphometrics analysis using craniofacial radiographs. Chungara 38:13-34.

Miyashita, K. 1996. Contemporary Cephalometric Radiography. Quintessence Publishing Co, Inc., Tokyo.

Moraga, M., C.M. Santoro, V.G. Standen, P. Carvallo, and F. Rothhammer 2005. Microevolution in prehistoric Andean populations: chronological mtDNA variation in the desert valleys of northern Chile. American Journal of Physical Anthropology 27:170-181.

Morton, S.G. 1839. Crania Americana or a Comparative View of the Skulls of Various Aboriginal Nations of North and South America. John Penington, Philadelphia.

Moss, M.L. 1960. A functional approach to craniology. American Journal of Physical Anthropology 18:281-292.

Moss, M.L. 1962. The functional matrix. In Vistas of Orthodontics, edited by B.S. Kraus and R.A. Riedel, pp. 85-98. Lea \& Febiger, Philadelphia.

Moss, M.L. 1969. The primary role of functional matrices in facial growth. American Journal of Orthodontics 55:566-577.

Moyers, R.E., and D.H. Enlow 1988. Growth of the craniofacial skeleton. In Handbook of Orthodontics, edited by R.E. Moyers, pp. 37-105. Year Book Medical Publishers, Inc., Chicago.

Muñoz, I. 1981. La aldea de Cerro Sombrero en el periodo del Desarrollo Regional de Arica. Chungara 7:105-144.

Muñoz, I. 1987. Enterramientos en túmulos en el valle de Azapa: nuevas evidencias para definir la fase Alto Ramírez en el extremo norte de Chile. Chungara 19:93-128.

Muñoz, I. 1989. El periodo formativo en el norte grande (1.000 a.C. a 500 d.C.). In Culturas de Chile Prehistoria: Desde sus Orígenes hasta los Albores de la Conquista, edited by J. Hidalgo, V. Schiappacasse, H. Niemeyer, C. Aldunate, and I. Solimano, pp. 107-128. Editorial Andrés Bello, Santiago.

O'Brien, T.G., and I.L. Sensor 2008. On the effect of cranial deformation in determining age from ectocranial suture closure. Growth Development and Aging 71:23-33. 
O'Loughlin, VD. 2004. Effects of different kinds of cranial deformation on the incidence of Wormian bones. American Journal of Physical Anthropology 123:146-155.

Oetteking, B. 1930. Craniology of the north Pacific coast. Memoirs of the American Museum of Natural History 15:1-391.

Ossenberg, NS. 1970. The influence of artificial cranial deformation on discontinuous morphological traits. American Journal of Physical Anthropology 33:357-372.

Pérez, S.I. 2007. Artificial cranial deformation in South America: a geometric morphometric approximation. Journal of Archaeological Science 34:1649-1658.

Piazza, F.K. 1981. Análisis descriptivo de una aldea Incaica en el sector de Pampa Alto Ramírez. Chungara 7:172-211.

Pomeroy, E., J.T. Stock, S.R. Zakrzewski, and M. Mirazon Lahr 2010. A metric study of three types of artificial cranial modification from north-central Peru. International Journal of Osteoarchaeology 20:317-334.

Proffett, W.R. 2007. Contemporary Orthodontics, Fourth Edition. Mosby Elsevier, St. Louis.

Ranly, D.M. 1988. A Synopsis of Craniofacial Growth. Appleton and Lange, Norwalk.

Rhode, M.P., and B.T. Arriaza 2006. Influence of cranial deformation on facial morphology among prehistoric south central Andean populations. American Journal of Physical Anthropology 130:462-470.

Riolo, M.L., R.E. Moyers, J.A. McNamara, and W.S. Hunter 1974. An Atlas of Craniofacial Growth. University of Michigan Press, Ann Arbor.

Rivera, M.A. 1977. Prehistoric Chronology of Northern Chile. Doctoral Dissertation, Department of Anthropology, University of Wisconsin, Madison.

Rivera, M.A. 2008. The archaeology of northern Chile. In Handbook of South American Archaeology, edited by H. Silverman and W. Isbell W., pp. 963-977. Springer, New York.

Rogers, S.L. 1975. Artificial deformation of the head: New World examples of ethnic mutilations and notes on its consequences. San Diego Museum Papers No 8. San Diego Museum of Man, California.

Ross, A.H., and D.H. Ubelaker 2009. Effect of intentional cranial modification on craniofacial landmarks: A three-dimensional perspective. Journal of Craniofacial Surgery 20:2185-2187.

Rothhammer, F., J.A. Cocilovo, S. Quevedo, and E. Llop 1982. Microevolution in prehistoric Andean populations: 1. Chronologic craniometric variation. American Journal of Physical Anthropology 58:391-396.

Rothhammer, F., C.M. Santoro, and M. Moraga 2002. Craniofacial chronological microdifferentiation of human prehistoric populations of the Azapa valley, northern Chile. Revista Chilena de Historia Natural 75:259-264.

Santoro, C. 1980a. Estratigrafía y secuencia cultural funeraria fases: Azapa, Alto Ramírez y Tiwanaku (Arica-Chile). Chungara 6:24-45.
Santoro, C. 1980b. Fase Azapa. Transición del Arcaico, al Desarrollo Agrario inicial en los valles bajos de Arica. Chungara 6:46-56.

Santoro, C. 1980c. Formativo temprano en el extremo norte de Chile. Chungara 8:33-62.

Santoro, C. 1981. Patrón habitacional Incaico en el área de Pampa Alto Ramírez (Arica, Chile). Chungara 7:144-171.

Santoro, C., and L. Ulloa 1985. Culturas de Arica. Universidad de Tarapacá, Arica.

Smith, H.F., C.E. Terhune, and C.A. Lockwood 2007. Genetic, geographic, and environmental correlates of human temporal bone variation. American Journal of Physical Anthropology 134:312-322.

Spradley, M.K. 2006. Biological Anthropological Aspects of the African Diaspora: Geographic Origins, Secular Trends, and Plastic versus Genetic Influences Utilizing Craniometric Data. Doctoral Dissertation, Department of Anthropology, University of Tennessee, Knoxville.

Thilander, B. 2012. Tissue reactions in orthodontics. In Orthodontics: Current Principles and Technique, edited by L.W. Graber, R.L. Vanarsdall Jr., and K.W.L. Vig, pp. 247-286. Elsevier, Philadelphia.

Torquemada, J. 1995 [1557-1664]. Monarquia indiana, libro catorce de la Tomo II. Biblioteca del estudiante universitario (Universidad Nacional Autonoma de Mexico): 83. 3rd Edition. Universidad Nacional Autónoma de México, Coordinación de Humanidades, México, D.F.

Torres-Rouff, C. 2002. Cranial vault modification and ethnicity in Middle Horizon San Pedro de Atacama, Chile. Current Anthropology 43:1-16.

Torres-Rouff, C. 2009. The bodily expression of ethnic identity: head shaping in the Chilean Atacama. In Bioarchaeology and Identity in the Americas, edited by K.J. Knudson and C.M. Stojanowski, pp. 212-230. University Press of Florida, Gainesville.

Ubelaker, D.H. 1999. Human Skeletal Remains: Excavation, Analysis, Interpretation. Taraxacum, Washington, D.C.

van Arsdale, A.P., and J.L. Clark 2010. Re-examining the relationship between cranial deformation and extra-sutural bone formation. International Journal of Osteoarchaeology 21:10.1002/oa.1188.

Varela, H.H. and J.A. Cocilovo 2002. Genetic drift and gene flow in a prehistoric population of the Azapa Valley and coast, Chile. American Journal of Physical Anthropology 118:259-267.

Verano, J.W. 1987. Cranial Microvariation at Pacatnamu: A Study of Cemetery Population Variability (Peru). Doctoral Dissertation, Department of Anthropology, University of California, Los Angeles.

Weiss, P. 1961. Osteología Cultural, Prácticas Cefálicas: $2 d a$ Parte, Tipología de las Deformaciones Cefálicas -- Estudio Cultural de los Tipos Cefálicos y de Algunas Enfermedades Oseas. Universidad Nacional Mayor de San Marcos, Perú. 

ANDROS IMPRESORES

www.androsimpresores.cl 
